\title{
Polyphosphate recovery by a native Bacillus cereus strain as a direct effect of glyphosate uptake
}

\author{
Alejandra Guadalupe Acosta-Cortés ${ }^{1} \cdot$ Cesar Martinez-Ledezma ${ }^{1}$ • Ulrico Javier López-Chuken ${ }^{2} \cdot$ Garima Kaushik $^{3}$. \\ Surendra Nimesh ${ }^{4} \cdot$ Juan Francisco Villarreal-Chiu (i) ${ }^{1}$
}

Received: 2 May 2018 / Revised: 15 January 2019 / Accepted: 22 January 2019 / Published online: 11 February 2019

(c) The Author(s) 2019. This article is published with open access

\begin{abstract}
Seven bacterial strains isolated from a glyphosate-exposed orange plantation site were exposed to $1 \mathrm{mM} \mathrm{N}$ (phosphonomethyl)glycine supplied as a phosphorus source. While some exhibited good biodegradation profiles, the strain $6 \mathrm{P}$, identified as Bacillus cereus, was the only strain capable of releasing inorganic phosphate to the culture supernatant, while accumulating polyphosphate intracellularly along the experimentation time. The composition and purity of the intracellular polyphosphate accumulated by the strain $6 \mathrm{P}$ were confirmed by FTIR analysis. To date, the biological conversion of glyphosate into polyphosphate has not been reported. However, given the importance of this biopolymer in the survival of microorganisms, it can be expected that this process could represent an important ecological advantage for the adaptation of this strain to an ecological niche exposed to this herbicide. The polyphosphate production yield was calculated as $4 \mathrm{mg} \mathrm{l}^{-1}$, while the glyphosate biodegradation kinetic constant was calculated on $0.003 \mathrm{~h}^{-1}$ using the modified HockeyStick first-order kinetic model, with a half-life of $279 \mathrm{~h}$. Our results suggest that B. cereus $6 \mathrm{P}$ is a potential candidate for the generation of an innovative biotechnological process to produce polyphosphate through the biodegradation of the herbicide glyphosate.
\end{abstract}

\section{Introduction}

Society has long depended on fertilizers for the improvement of crop productivity [1]. From manure and human excreta to guano and phosphate rock, the use of phosphorus $(\mathrm{P})$ to increase crop yields has become inevitable for coping with the exponential growth of human population [2]. In 2009, more

Juan Francisco Villarreal-Chiu

juan.villarrealch@uanl.edu.mx

1 Universidad Autónoma de Nuevo León, Facultad de Ciencias Químicas, Laboratorio de Biotecnología. Av, Universidad S/N Ciudad Universitaria, San Nicolás de los Garza, Nuevo León 66455, Mexico

2 Universidad Autónoma de Nuevo León, Facultad de Ciencias Químicas, Laboratorio de Investigación en Ciencias Ambientales. Av, Universidad S/N Ciudad Universitaria, San Nicolás de los Garza, Nuevo León 66455, Mexico

3 Department of Environmental Science. School of Earth Science, Central University of Rajasthan, Ajmer, Rajasthan 305817, India

4 Department of Biotechnology. School of Life Sciences, Central University of Rajasthan, Ajmer, Rajasthan 305817, India than $21 \mathrm{Mt}$ of elemental P was extracted from phosphate rock, of which almost $18 \mathrm{Mt}$ were used as fertilizers [3]. Despite its effectivity in promoting plant growth [4], nearly $100 \%$ of $\mathrm{P}$ consumed by animals and humans is excreted [5], leading to an increasing input of $\mathrm{P}$ across urban and rural land-water interfaces [6]. The resulting excess of nutrients in the environment is directly responsible for the extraordinary growth of algae that generate the eutrophication of surface water bodies worldwide [7]. It has been estimated that $\mathrm{P}$ recovery from wastewaters would not only avoid eutrophication in surface waters and coastal zones, but it would also offer a renewable source of $\mathrm{P}$ that could benefit the predicted phosphate rock scarcity in the near future [8].

Nowadays, the recovery of $\mathrm{P}$ from wastewater is usually attained by the chemical precipitation of struvite [9] or hydroxyapatite [10]. It can also be obtained by the production of P-rich sludges by a microbial process known as enhanced biological phosphorus removal (EBPR) [11]. The P-rich products of such methods can be directly used as plant fertilizers with the same effectivity as mineral phosphate [12], making these processes economically attractive [13]. Moreover, purified $\mathrm{P}$ in the form of polyphosphate (polyP) can be obtained directly from EBPR biosolids by 
biological [14] or thermal-chemical methods [15]. This biopolymer can be furtherly used in the synthesis of anticorrosion pigments [16, 17], fish processing [18, 19], and water treatment [20]. So, as global reserves of high-quality phosphate rock are becoming limited and its use by industries continues proliferating, the development of new strategies for recycling $\mathrm{P}$ becomes an important issue for future food security [21].

Despite the successful implementation of EBPR in wastewater treatment plants around the world, some forms of organophosphorus compounds, including organophosphate pesticides, are not entirely metabolized by polyphosphate-accumulating organisms. Many of these compounds are known to persist in ecosystems and have been associated with several diseases in humans [22]. Glyphosate, for example, has been linked with DNA damage and apoptosis in human cell lines [23-26]. For hence, the International Agency for Research on Cancer has classified this compound as a possible carcinogen [27]. Therefore, it is important to develop new strategies and biotechnological processes that could facilitate the control or elimination of this compound from wastewater and industrial sludges before its liberation to the environment resulting in the contamination of drinking water sources.

In this study, we present a novel strategy for the recovery of high-quality polyP through the uptake of glyphosate by a native Bacillus cereus strain. The release of inorganic phosphate (Pi) to the culture supernatant and the accumulation of intracellular polyP suggests that the Bacillus cereus strain designated as $6 \mathrm{P}$ is capable to metabolize glyphosate on a Pi-insensitive manner.

\section{Materials and methods}

\section{Soil sample collection}

A soil sample from a glyphosate-exposed orange plantation site located in the north-eastern Mexican State of Nuevo

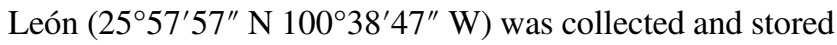
in sterilized bags at $4{ }^{\circ} \mathrm{C}$ according to the Mexican environmental standard NMX-AA-132-SCFI-2006 (ref. 28). The site's composite sample was sieved to eliminate roots and plant debris, and furtherly analyzed for humidity, $\mathrm{pH}$, organic matter, exchangeable $\mathrm{P}$, inorganic nitrogen and type of soil according to the Mexican environmental standard NOM-147-SEMARNAT/SSA1-2004 [29].

\section{Biomass acclimation and isolation of culturable bacterial strains}

Biomass acclimation was carried out by adding $10 \mathrm{~g}$ of the site's composite sample to $200 \mathrm{~mL}$ of LB broth supplemented with $100 \mathrm{ppm}$ of the commercial glyphosate trade name Faena Fuerte 360 . The batch bioreactor was incubated at $28{ }^{\circ} \mathrm{C}$ under aerobic conditions for 28 days, replenishing with fresh acclimation medium every seven days. At the end of the acclimation period, $10 \mathrm{~mL}$ aliquots of the microbial suspensions were washed with a sterile saline solution and preserved for further use in glycerol $25 \%$ at $-20{ }^{\circ} \mathrm{C}$.

The acclimatized-biomass was submitted to a serial dilution technique to isolate the culturable bacterial strains present in the consortium. The serial dilution was carried out in LB broth incubated at $28^{\circ} \mathrm{C}$ and $150 \mathrm{rpm}$ for $48 \mathrm{~h}$, plating on $\mathrm{LB}$ agar and incubated at $28^{\circ} \mathrm{C}$ for 3 days. Seven morphologically different colonies from the crowding on the surface of LB agar were selected and purified by repeated sub-culturing in LB media. The purified strains were preserved as described previously.

\section{Screening for polyphosphate accumulation by glyphosate-acclimatized bacterial isolates}

The seven bacterial isolates were tested to evaluate their individual biological capacity to accumulate polyP as a direct effect of glyphosate uptake. These experiments were performed on minimal mineral medium (MMM), containing: $\mathrm{MgSO}_{4} \cdot 7 \mathrm{H}_{2} \mathrm{O}(0.2 \mathrm{~g}), \mathrm{KCl}(0.2 \mathrm{~g}), \mathrm{CaCl}_{2} \cdot 2 \mathrm{H}_{2} \mathrm{O}$ $(0.001 \mathrm{~g}), \mathrm{Fe} \cdot \mathrm{NH}_{4} \cdot$ Citrate $(0.001 \mathrm{~g}), \mathrm{SL}-4$ trace elements solution $(1 \mathrm{~mL}$; [30]) and MEM vitamin solution $(1 \mathrm{~mL}$; Sigma-Aldrich, St. Louis, USA) in $1 \mathrm{~L}$ of distilled water. As a control, the MMM was supplemented with nutrients equivalent to Redfield's ratio: sodium acetate $110 \mathrm{mM}$, $\mathrm{NH}_{4} \mathrm{Cl} 14 \mathrm{mM}$ and $\mathrm{NaH}_{2} \mathrm{PO}_{4} 1 \mathrm{mM}$ as carbon, nitrogen and phosphorus sources respectively. For bioassays, N-(phosphonomethyl)glycine 96\% (Sigma-Aldrich, St. Louis, USA) was supplied as a source of phosphorus $(1 \mathrm{mM})$ instead of $\mathrm{NaH}_{2} \mathrm{PO}_{4}$ used in the control.

All bioassays were performed in triplicate using $125 \mathrm{~mL}$ Erlenmeyer flasks containing $30 \mathrm{~mL}$ of experimental MMM adjusted to an initial $0.05 \mathrm{OD}_{620}$ of each bacterial isolate. Experimental flasks were incubated at $28^{\circ} \mathrm{C}$ and $150 \mathrm{rpm}$ in a MaxQ 4000 orbital shaker (Thermo Fisher Scientific; Waltham, USA). End-point samples were collected after $120 \mathrm{~h}$ of experimentation and analyzed for 1) microbial growth, quantified by the increase in total proteins following the Bradford assay [31] using a Cary 50 spectrophotometer (Agilent Technologies; Santa Clara, USA); 2) glyphosate concentration in experimental supernatants, determined by the spectrophotometric method described by Waiman et al.; [32] 3) release of inorganic phosphate to the culture supernatant during catabolism, assayed using the BioMol-Green reagent (ENZO Life Sciences; Farmingdale, USA) following the manufacturer's protocol; 4) monitoring of intracellular polyP granules, visualized by staining the 
cells with $500 \mu \mathrm{g} / \mathrm{mL}$ DAPI in $25 \mathrm{mM}$ Tris- $\mathrm{HCl}$ at $\mathrm{pH} 7.0$ as described by Kulakova et al. [33]. Stained cells were visualized at 1000x using a Leica DM-3000 fluorescent microscope with a DAPI filter cube (Leica Microsystems; Wetzlar, Germany); and 5) monitoring of intracellular polyhydroxyalkanoate (PHA) granules as response to cellular nutritional stress, visualized by staining the cells with $30 \mu \mathrm{L}$ Nile red $1 \%$ as described by Tan et al. [34] and observed at 1000x using fluorescence microscopy with a Texas Red filter cube.

\section{Extraction and characterization of intracellular polyphosphate}

Intracellular polyP granules were extracted according to the methodology described by Kulakova et al. [33], in which the bacterial pellet attained from $10 \mathrm{~mL}$ of culture media was resuspended in $50 \mu \mathrm{L} \mathrm{H}_{2} \mathrm{SO}_{4} 1 \mathrm{M}$ and incubated at room temperature for $5 \mathrm{~min}$. This mix was neutralized with $50 \mu \mathrm{L} \mathrm{NaOH} 2 \mathrm{M}$ and added $100 \mu \mathrm{L}$ of Tris- $\mathrm{HCl} \mathrm{pH}$ 7. The remaining mix was centrifuged at 13,000 r.p.m. for $5 \mathrm{~min}$, and $600 \mu \mathrm{L} \mathrm{NaI} 6 \mathrm{M}$ along with $600 \mu \mathrm{L}$ of isopropyl alcohol were added to the supernatant. After final centrifugation at $13000 \mathrm{rpm}$ for $5 \mathrm{~min}$, the polyP pellet was submitted to a Spectrum 100 FTIR spectrometer (PerkinElmer Inc; Waltham, USA), using 50 scans at $4 \mathrm{~cm}^{-1}$ resolution. The spectra were recorded in the region of $4000-650 \mathrm{~cm}^{-1}$ using a $\mathrm{KBr}$ window for solutions.

\section{Polyphosphate production yield and glyphosate biodegradation kinetics}

The polyphosphate-accumulating bacterial isolate designated as $6 \mathrm{P}$ was submitted to a kinetic study to evaluate its efficiency to biodegrade glyphosate along with its capacity to accumulate polyP. This bioassay was performed in triplicate using $125 \mathrm{~mL}$ Erlenmeyer flasks containing $30 \mathrm{~mL}$ of experimental MMM supplemented with N-(phosphonomethyl)glycine $96 \%$ as a phosphorus source $(1 \mathrm{mM})$, adjusted to an initial $0.05 \mathrm{OD}_{620}$ of the microbial suspension. Experimental flasks were incubated at $28^{\circ} \mathrm{C}$ and $150 \mathrm{rpm}$ for $240 \mathrm{~h}$. Samples were collected every $24 \mathrm{~h}$ during the first $120 \mathrm{~h}$, and after that, every $48 \mathrm{~h}$ until the completion of the experiment. Experimental samples were analyzed for the following: (1) microbial growth; (2) glyphosate concentration in experimental supernatants; and (3) release of inorganic phosphate to the culture supernatant during catabolism as described previously. Polyphosphate production yield was determined as dry weight of the intracellular polyP extracted according to Kulakova et al. [33] per litre of culture.

The glyphosate biodegradation rate constants were calculated using the modified Hockey-Stick model [35]. The
Table $116 \mathrm{~s}$ rRNA gene sequences of representative members of the Firmicutes phylum used in the phylogenetic analysis

\begin{tabular}{lll}
\hline Microorganism & Strain code & Accession number \\
\hline $\begin{array}{l}\text { Related members of the genus } \\
\text { B. cereus }\end{array}$ & ATCC 14579 & AF290547.1 \\
& ATCC 27877 & Z84581.1 \\
& ATCC 10987 & AJ577290.1 \\
& ATCC 4342 & AJ577288.1 \\
B. subtilis & CCM 1999 & DQ207730.2 \\
B. licheniformis & B-6-4J & D31739.1 \\
B. anthracis & ATCC 10340 & AB190217.1 \\
B. clausii & DSM 8716 & X76440.1 \\
B. megaterium & C1 & AJ491841.1 \\
Related members of the phylum & Firmicutes & \\
Lactobacillus gallinarum & ATCC 3319 & AJ242968.1 \\
Lactobacillus amylotrophicus & NRRL B-4435 & AM236150.1 \\
Clostridium argentinense & ATCC 27322 & NR_029232.1 \\
Clostridium tertium & ATCC 14573 & AJ245413.1 \\
Staphylococcus aureus & ATCC 25923 & U02910.1 \\
\hline
\end{tabular}

following equations related to this method were used:

$$
\begin{aligned}
& C=C_{0} \text { for }: t \leq t_{\mathrm{b}}, \\
& C=C_{0} e^{-k(t-t b)} \text { for }: t>t_{\mathrm{b}},
\end{aligned}
$$

where $C$ is the concentration of glyphosate at time $t, C_{0}$ is the concentration of glyphosate applied at time $t=0$ in the experimental assay, $k$ is the biodegradation rate constant of glyphosate and $t_{\mathrm{b}}$ is the breakpoint at the time at which rate constant changes and biodegradation start.

Glyphosate half-life $\left(T_{1 / 2}\right)$ was calculated according the following equation: [35]

$$
T_{1 / 2}=t_{\mathrm{b}}+\ln 2 / K \text {. }
$$

\section{Identification of the polyphosphate-accumulating isolate $6 \mathrm{P}$}

The identity of the bacterial isolate designated as $6 \mathrm{P}$ was confirmed by the $16 \mathrm{~s}$ rRNA sequence alignment with the non-redundant nucleotide database held in the National Center for Biotechnology Information (NCBI), using the Basic Local Alignment Search Tool (nucleotide BLAST, http://blast.ncbi.nlm.nih.gov/Blast). To do so, DNA from the bacterial isolate was extracted using a PrepEase ${ }^{\circledR}$ Genomic DNA Isolation Kit (Thermo Fischer Scientific Inc; Waltham, USA) following the manufacturer's protocol. DNA was resuspended in Tris $10 \mathrm{mM}(\mathrm{pH} \mathrm{8.0)}$ ) and quantified with a NanoDrop ND-1000 spectrophotometer 
Table 2 Chemical characteristics of the glyphosate-exposed orange plantation sample

\begin{tabular}{lllllll}
\hline Location & $\mathrm{pH}$ & Humidity $(\%)$ & $\begin{array}{l}\text { Organic matter } \\
(\%)\end{array}$ & Exchangeable P (ppm) & $\begin{array}{l}\text { Inorganic nitrogen } \\
(\%)\end{array}$ & Type of soil \\
\hline $25^{\circ} 57^{\prime} 57^{\prime \prime} \mathrm{N}$ & 7.75 & 19.46 & 1.21 & 22.16 & 0.07 & $\begin{array}{l}\text { Vertisol (Clay } 41 \%, \text { Silt } 53 \%, \text { Sand } \\
100^{\circ} 38^{\prime} 47^{\prime \prime} \mathrm{W}\end{array}$ \\
& & & & & $6 \%)$
\end{tabular}

(NanoDrop Technologies; Wilmington, USA). $1.6 \mu \mathrm{g} / \mu \mathrm{l}$ of the DNA template was used for the PCR amplification of the 16s rRNA gene, performed using the universal primers 27 F (5'-AGAGTTTGATCCTGGCTCAG-3') y 132 R (5'GGTTACCTTGTTACGACTT3'). The PCR reaction was carried out in a Mastercycler ${ }^{\circledR}$ pro thermocycler (Eppendorf AG; Hamburg, Germany) with the following program: $94{ }^{\circ} \mathrm{C}$ for $4 \mathrm{~min}$, followed by 35 cycles of $92^{\circ} \mathrm{C}$ for $1.5 \mathrm{~min}$, $50{ }^{\circ} \mathrm{C}$ for $1.5 \mathrm{~min}, 72^{\circ} \mathrm{C}$ for $2 \mathrm{~min}$, and completing with $72{ }^{\circ} \mathrm{C}$ for $10 \mathrm{~min}$. The purified PCR product was submitted to Macrogen Corp. (Rockville, USA) for sequencing.

To corroborate the molecular identity of the strain $6 \mathrm{P}$, the resulting 16s rRNA gene sequence was aligned against 14 representative members of the phylum Firmicutes (Table 1) using ClustalW. The phylogenetic tree was computed by the Minimum Evolution method using the MEGA 7 software with 1000 bootstrap repetitions [36, 37].

\section{Results and discussions}

\section{Screening for polyphosphate accumulation by glyphosate-acclimatized bacterial isolates}

Seven bacterial strains were isolated from a glyphosateexposed orange plantation sample, which chemical characteristics are reported in Table 2. These isolates were exposed to $1 \mathrm{mM} N$-(phosphonomethyl)glycine supplied as phosphorus source and exhibited different patterns of growth and glyphosate consumption (Fig. 1). While strains $1 \mathrm{P}, 4 \mathrm{P}, 5 \mathrm{P}$, and $6 \mathrm{P}$ could be considered as potential candidates for the development of a glyphosate biodegradation process due to the significant increase of total proteins and the decrease of glyphosate concentration in the culture supernatant, only the strain $6 \mathrm{P}$ was able to release $\mathrm{Pi}$ to the supernatant (Fig. 1) and accumulate polyP intracellularly (Fig. 2) after $120 \mathrm{~h}$ of experimentation.

Glyphosate biodegradation by soil bacteria has been reported extensively since 1977 [38-43]. However, to date, there has not been reported a process of accumulation of polyP occurring in conjunction with the biodegradation of this herbicide. This is due because the cleavage of glyphosate's C-P bond has been demonstrated to be universally dependent on the concentration of inorganic phosphate present in the surrounding environment of the cell [44-48]. The in-vivo C-P lyase activity, enzyme

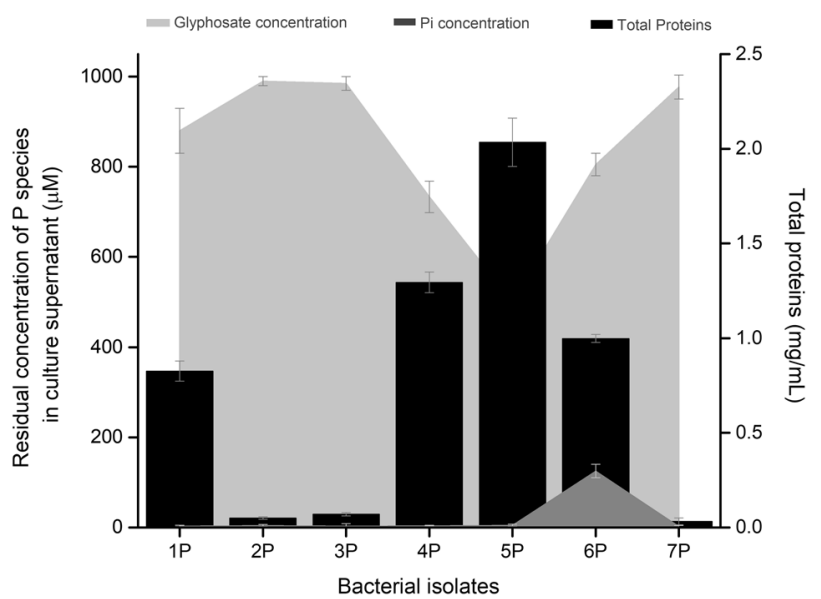

Fig. 1 Profiles of microbial growth and concentration of phosphorus species (glyphosate and inorganic phosphate) in the culture supernatant after $120 \mathrm{~h}$ of experimentation by bacterial isolates grown on $\mathrm{N}$ (phosphonomethyl)glycine $96 \%$ as a phosphorus source $(1 \mathrm{mM})$. Error bar represents standard deviation $(n=3)$

responsible for the cleavage of glyphosate's C-P bond, has been confirmed to be both physiologically and genetically regulated as a member of the Pho regulon, which is expressed under phosphate limitation conditions [45, 49, 50]. While the concentration by which the Pho regulon may be activated varies between organisms, it has been accepted that inorganic phosphate concentrations below $4 \mu \mathrm{M}$ leads to the activation of the two-component regulatory system $\mathrm{PhoR}-\mathrm{PhoB}$ responsible for the expression of $\mathrm{C}-\mathrm{P}$ lyase and other $\mathrm{P}$-scavenging genes [51, 52]. Therefore, the biosynthesis of the $\mathrm{C}-\mathrm{P}$ lyase is repressed by the Pi released during the degradation of the herbicide, which in turn, inhibits the complete mineralization of the phosphonate molecule and any potential accumulation of intra- or extracellular Pi [53].

Interestingly, the strain $6 \mathrm{P}$ did not exhibit an accumulation of PHA granules in comparison with the rest of the studied isolates (Fig. 3). This is important because PHA has long been reported as a mechanism of survivability and adaptation against microbial stress [34]. As PHA tend to be accumulated under Pi-limitation (as well as other nutrients, such as nitrogen, oxygen, among others) [54], it can be inferred that this isolate was not under metabolic stress during the experiment. This suggests the strain $6 \mathrm{P}$, in contrast of the rest of the studied microorganisms, was able to obtain a continuous supply of $\mathrm{Pi}$ from $\mathrm{N}$ - 
Fig. 2 Fluorescence microscopic analysis for the evaluation of polyP accumulation by glyphosate-acclimatized bacterial isolates grown on $1 \mathrm{M}$ $\mathrm{N}$-(phosphonomethyl)glycine $96 \%$ as sole phosphorus source. Bacterial cells from strains $1 \mathrm{P}, 2$ $\mathrm{P}, 3 \mathrm{P}, 4 \mathrm{P}, 5 \mathrm{P}, 6 \mathrm{P}$, and $7 \mathrm{P}$ stained with DAPI after $120 \mathrm{~h}$ of incubation

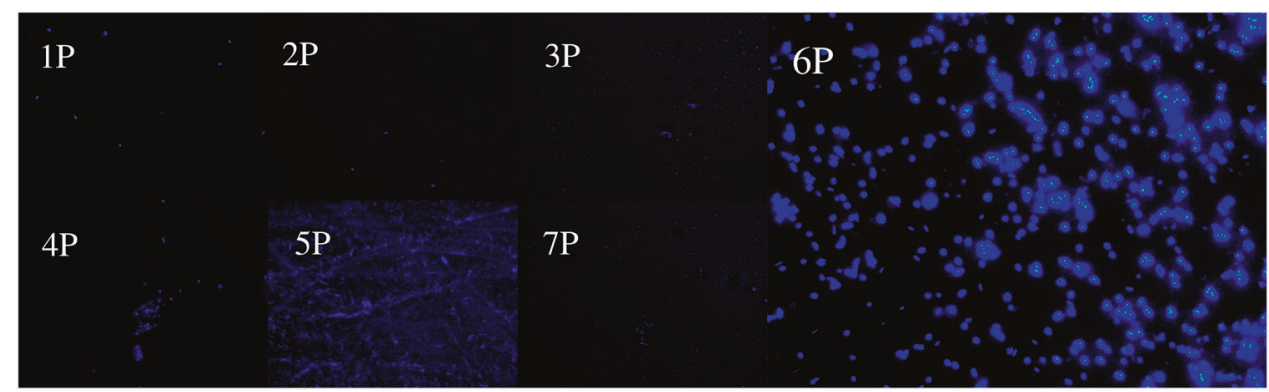

Fig. 3 Fluorescence microscopic analysis for the evaluation of nutritional stress on glyphosateacclimatized bacterial isolates grown on $1 \mathrm{M} \mathrm{N}$ -

(phosphonomethyl)glycine 96\% as sole phosphorus source.

Bacterial cells from strains $1 \mathrm{P}, 2$ $\mathrm{P}, 3 \mathrm{P}, 4 \mathrm{P}, 5 \mathrm{P}, 6 \mathrm{P}$, and $7 \mathrm{P}$ stained with Nile red $1 \%$ after $120 \mathrm{~h}$ of incubation

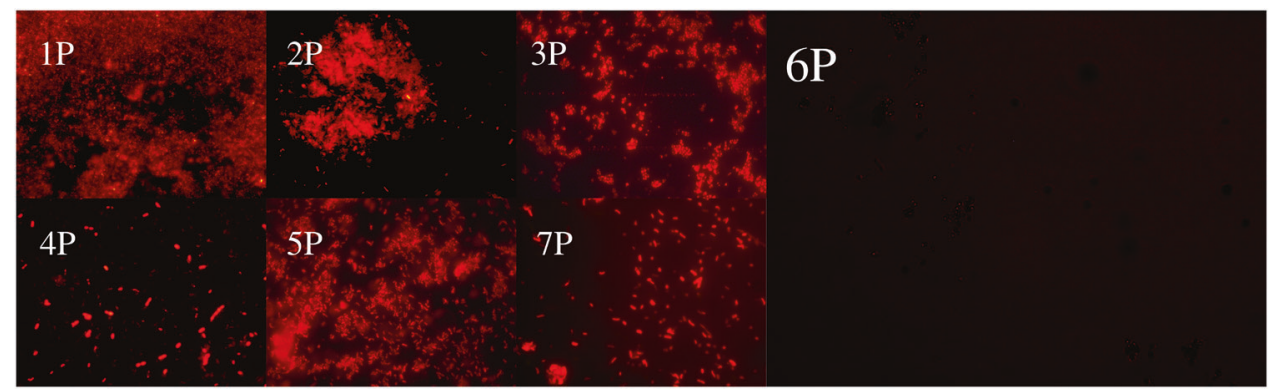

(phosphonomethyl)glycine, which was supplied as the only available source of $\mathrm{P}$. Moreover, the strain $6 \mathrm{P}$ was able to accumulate the excess of $\mathrm{Pi}$ in the form of internal polyP granules, and even release part of it to the culture supernatant, as descrived previously.

\section{Extraction and characterization of intracellular polyphosphate}

As observed in Fig. 4, the FTIR spectrum of the biomaterial extracted from the biomass of the strain $6 \mathrm{P}$ showed strong bands at 900 and $1100 \mathrm{~cm}^{-1}$. These have been associated with the $\mathrm{P}-\mathrm{O}$ and $\mathrm{P}=\mathrm{O}$ bonds present in the phosphate moiety of polyP [55]. The absence of additional bands in the spectrum suggests that no additional chemical elements or functional groups are present in the molecular structure of the analyzed material, discarding the presence of organophosphorus compounds [56]. Therefore, we concluded the identity of the biomaterial to be polyphosphate. The purity observed in the FTIR spectrum suggest that the strain $6 \mathrm{P}$ can produce high-quality polyP and can be considered as a potential candidate for the generation of an innovative biotechnological process to produce this important biopolymer through the biodegradation of the herbicide glyphosate.

\section{Polyphosphate production yield and glyphosate biodegradation kinetics}

A more detailed study on the glyphosate biodegradation kinetics by the strain $6 \mathrm{P}$ demonstrated that Pi concentration remained undetected in the culture supernatant for the first

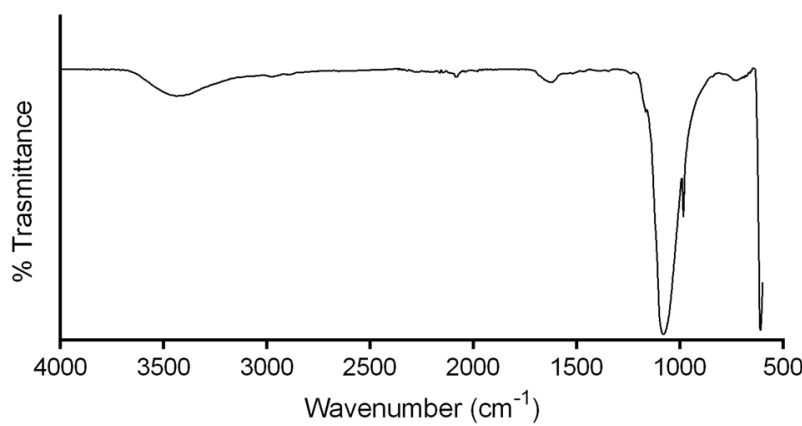

Fig. 4 Fourier transform infra-red spectrum of purified polyphosphate extracted from the biomass of the bacterial isolate $6 \mathrm{P}$ grown on $1 \mathrm{M}$ $\mathrm{N}$-(phosphonomethyl)glycine $96 \%$ as sole phosphorus source

$96 \mathrm{~h}$ of experimentation (Fig. 5a). According to the manufacturer, the BIOMOL $^{\circ}$ Green method is capable of detecting Pi concentrations down to $0.5 \mu \mathrm{M}$, which coincide with the ideal condition for the induction of the $\mathrm{C}-\mathrm{P}$ lyase $[51,52,57]$. However, after this period, Pi levels rose above the C-P lyase induction concentration until reaching nearly $20 \%$ of the initial glyphosate concentration at the end of the experimentation time. These Pi levels are known to have inhibited the C-P lyase activity of many bacterial species, including Acidithiobacillus ferrooxidans [58], Trichodesmium erythraeum [59], and Escherichia coli [45]. Despite this paradox, the continuous increase of total proteins observed along the experiment suggests that cells of the strain $6 \mathrm{P}$ were biologically active, being able of utilizing glyphosate as a source of $\mathrm{P}$ for microbial growth in a $\mathrm{Pi}$-insensitive manner. Moreover, the strain $6 \mathrm{P}$ was able to accumulate part of the excess $\mathrm{Pi}$ as PolyP granules, which 


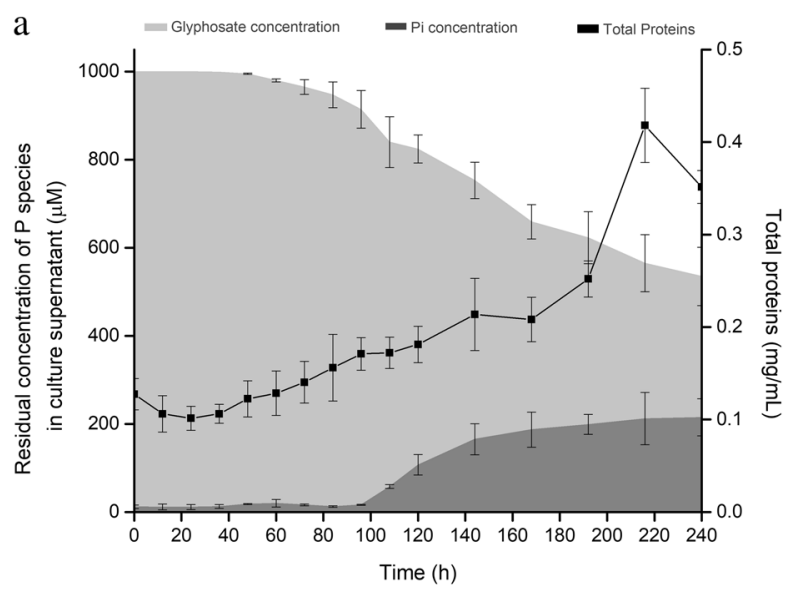

Fig. 5 a Growth curve of the glyphosate-acclimatized bacterial isolate $6 \mathrm{P}$ in MMM containing $1 \mathrm{M} \mathrm{N}$-(phosphonomethyl)glycine $96 \%$ as sole phosphorus source, and changes in the concentration of phosphorus species (glyphosate and inorganic phosphate) in the culture

were visualized only after $120 \mathrm{~h}$ of experimentation, reaching a final production yield of $4 \mathrm{mg}^{-1}$.

Pi-insensitive degradation of glyphosate is a rare phenomenon. It was first reported in Alcaligenes sp. GL. This bacterial strain exhibited a base level of glyphosate degrading activity during growth in the presence of $\mathrm{Pi}$ or in complex media. However, the complete removal of Pi from the medium caused a drastic stimulation of glyphosate uptake [60]. On the other hand, the mutant Arthrobacter sp. GLP-1/Nit-1 was capable to excrete $90 \%$ of the glyphosatederived phosphorus when this phosphonate was supplied as nitrogen and phosphorus source. Nevertheless, the native strain Arthrobacter sp. GLP-1 was able to utilize glyphosate only in the absence of $\mathrm{Pi}$ [61]. To date, a true $\mathrm{Pi}$ independency has only been reported on the biodegradation of biogenic phosphonates by environmental strains that possess analog enzymes of phosphonatase [62], phosphonoacetate hydrolase [63, 64], and phosphonopyruate hydrolase $[65,66]$. Therefore, the Pi-insensitive degradation of glyphosate by $B$. cereus $6 \mathrm{P}$ is noteworthy and represent a feasible biotechnological process to mineralize glyphosate under environmental conditions.

The biodegradation of glyphosate was adjusted to a modified Hockey-Stick first-order kinetic model (Fig. 5b). This mathematical equation, which is commonly used for the calculation of pesticides biodegradation rates [35], describes the behavior of a pesticide where the initial concentration is not constant but declines very slowly up to a breakpoint $\left(\mathrm{t}_{\mathrm{b}}\right)$. As shown in Fig. 5a, this breakpoint was observed at $48 \mathrm{~h}$ of experimentation, when glyphosate concentration began to decrease faster, reaching a final concentration of $623 \mu \mathrm{M}$. The kinetic constant was calculated on $0.003 \mathrm{~h}^{-1}$ and the glyphosate half-life on $279 \mathrm{~h}$.

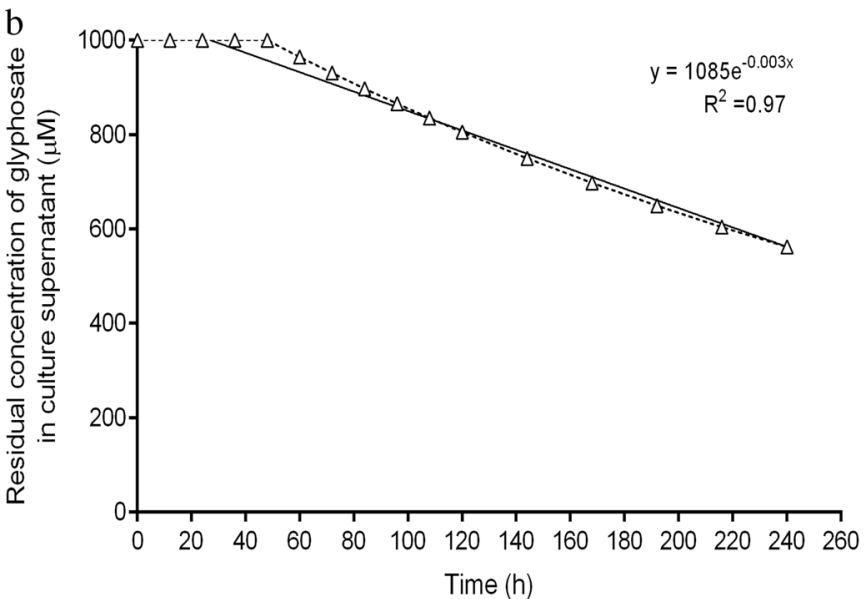

supernatant at various stages of cellular growth. Error bar represents standard deviation $(n=3)$; (b) modeling of the glyphosate biodegradation kinetics by the modified Hockey-Stick mathematical model

\section{Identification of the polyphosphate-accumulating isolate $6 \mathrm{P}$}

The resulting nucleotide sequence established that the strain $6 \mathrm{P}$ belonged to the Bacillus cereus species with a $97 \%$ identity based on the BLASTN analysis. When compared with other members of the Firmicutes phylum, the strain $6 \mathrm{P}$ clustered along with other $B$. cereus species, confirming the identity of this native bacterial isolate (Fig. 6). This result is consistent with the natural occurrence and distribution of the species, since the cells and spores of $B$. cereus are present in a wide variety of environmental niches, mainly as components of the rhizomicrobiota present in soil, in endophytic communities of growing plants, or as potential pathogens of insects and mammals [67]. Having been isolated from different soils dedicated to agriculture [68, 69], the presence of a strain of B. cereus in an orange plantation site may be expected.

On the other hand, the biological capability to accumulate polyP is widely distributed among Firmicutes, since these commonly synthesize it to attain certain ecological advantages [70]. This molecule, rich in high-energy phosphoanhydride bonds, is known to act not only as a phosphate and energy storage material, but also as a key player in several physiological processes, such as flagellar mobility, biofilm development, quorum sensing and virulence [71]. By regulating the mechanism of response to stresses and stringencies, PolyP molecule increases the survivability of these microorganisms under unfavorable growth conditions [72]. Moreover, in B. cereus, the role of polyP has also been associated with the sporulation process, with polyP levels dropping rapidly when spore formation begins [73]. This suggests that the strain $6 \mathrm{P}$ may be able to metabolize the glyphosate present in agricultural soils to provide the 


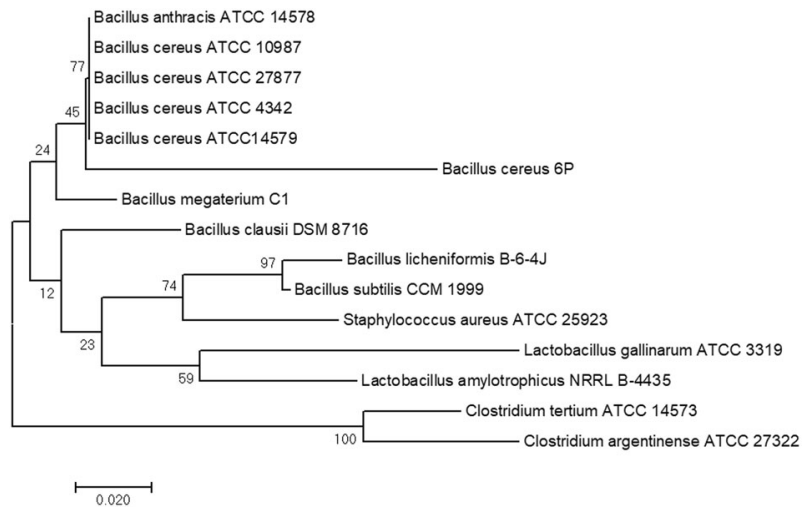

Fig. 6 Phylogenetic tree showing the relationship between Bacillus cereus $6 \mathrm{P}$ and 14 representatives of the Firmicutes phylum as inferred by the Minimum Evolution method. The percentage of replicate trees in which the associated taxa clustered together in the bootstrap test (1000 replicates) are shown next to the branches

cell with a phosphate and energy storage material that could be used later in the sporulation process, assuring its longterm survival when faced with unfavorable growth conditions.

In conclusion, we have shown that the native bacterial isolate, designated as Bacillus cereus $6 \mathrm{P}$, is capable of accumulating intracellular polyP in response to the uptake of glyphosate as a source of P. As this process occurred independently of the Pi present in the culture supernatant, it can be suggested that $B$. cereus $6 \mathrm{P}$ is currently the only bacterial strain capable of metabolizing glyphosate in a Piinsensitive manner. In ecological terms, this would allow B. cereus $6 \mathrm{P}$ and related species to accumulate PolyP in sites exposed to glyphosate before members of other species and phyla. Being directly related to the sporulation process, this new biological process would help ensure the long-term survival of this bacterial strain. On the other hand, the reaction conditions described in this work would overcome the existing biological limitations for the development of an efficient biotechnological process capable of mineralizing this herbicide. However, more work is required to determine its potential application for phosphorus recovery as part of the strategy for future food security, and all the ecological implications of this new process represents for the bacteria that are usually present in soils rich in glyphosate.

Acknowledgements We gratefully acknowledge the generous financial support from PROMEP/103.5/13/6644 and UANL-CA-372 Research Grants and the Mexico-India Bilateral Cooperation Project 266482 Mobility Grant provided by CONACYT-DST.

\section{Compliance with ethical standards}

Conflict of interest The authors declare no competing financial interests.
Publisher's note: Springer Nature remains neutral with regard to jurisdictional claims in published maps and institutional affiliations.

Open Access This article is licensed under a Creative Commons Attribution 4.0 International License, which permits use, sharing, adaptation, distribution and reproduction in any medium or format, as long as you give appropriate credit to the original author(s) and the source, provide a link to the Creative Commons license, and indicate if changes were made. The images or other third party material in this article are included in the article's Creative Commons license, unless indicated otherwise in a credit line to the material. If material is not included in the article's Creative Commons license and your intended use is not permitted by statutory regulation or exceeds the permitted use, you will need to obtain permission directly from the copyright holder. To view a copy of this license, visit http://creativecommons. org/licenses/by/4.0/.

\section{References}

1. Fageria NK. The use of nutrients in crop plants. Boca Raton, FL. USA: CRC Press; 2008. p. 448.

2. Cordell D, Drangert JO, White S. The story of phosphorus: Global food security and food for thought. Glob Environ Chang. 2009;19:292-305.

3. Koppelaar RHEM, Weikard HP. Assessing phosphate rock depletion and phosphorus recycling options. Glob Environ Chang. 2013;23:1454-66.

4. Raghothama KG, Karthikeyan AS. Phosphate acquisition. Plant Soil. 2005;274:37-49.

5. Jönsson H, Stintzing AR, Salomon E. Guidelines on the use of urine and faeces in crop production. Rosemarin A, editor. Stockholm: the EcoSanRes Programme and the Stockholm Environment Institute This; 2004. p. 35.

6. Withers P, Neal C, Jarvie H, Doody D. Agriculture and eutrophication: where do we go from here? Sustainability. 2014;6:5853-75.

7. De-Bashan LE, Bashan Y. Fertilizer potential of phosphorus recovered from wastewater treatments. In: First International Meeting on Microbial Phosphate Solubilization. (Springer, Dordrecht, Netherlands) 2007. p. 179-84.

8. Acevedo B, Camiña C, Corona JE, Borrás L, Barat R. The metabolic versatility of PAOs as an opportunity to obtain a highly P-enriched stream for further P-recovery. Chem Eng J. 2015;270:459-67.

9. Xia CW, Ma YJ, Zhang F, Lu YZ, Zeng RJ. A novel approach for phosphorus recovery and No wasted sludge in enhanced biological phosphorus removal process with external COD addition. Appl Biochem Biotechnol. 2014;172:820-8.

10. Dai H, Lu X, Peng Y, Yang Z, Zhsssu H. Effects of supersaturation control strategies on hydroxyapatite (HAP) crystallization for phosphorus recovery from wastewater. Environ Sci Pollut Res. 2017;24:5791-9.

11. Yuan Z, Pratt S, Batstone DJ. Phosphorus recovery from wastewater through microbial processes. Curr Opin Biotechnol. 2012;23:878-83.

12. Erdincler A, Seyhan LD. Agricultural use of municipal wastewater sludges: phosphorus availability of biological excess phosphorus removal sludges. Water Sci Technol. 2006;54:131-8.

13. Molinos-Senante M, Hernández-Sancho F, Sala-Garrido R. Economic feasibility study for new technological alternatives in wastewater treatment processes: a review. Water Sci Technol. 2012;65:898-906.

14. Barr JJ, Slater FR, Fukushima T, Bond PL, KE W, JA F, et al. Evidence for bacteriophage activity causing community and 
performance changes in a phosphorus-removal activated sludge. FEMS Microbiol Ecol. 2010;74:631-42.

15. Hirota R, Kuroda A, Kato J, Ohtake H. Bacterial phosphate metabolism and its application to phosphorus recovery and industrial bioprocesses. J Biosci Bioeng. 2010;109:423-32.

16. $\mathrm{Lu} \mathrm{Q}, \mathrm{Hu} \mathrm{Y}$. Synthesis of aluminum tri-polyphosphate anticorrosion pigment from bauxite tailings. Trans Nonferrous Met Soc China. 2012;22:483-8.

17. Deyá C, Blustein G, del Amo B, Romagnoli R. Evaluation of ecofriendly anticorrosive pigments for paints in service conditions. Prog Org Coatings. 2010;69:1-6.

18. Boyd JW, Southcott BA. Effect of polyphosphates and other salts on drip loss and oxidative rancidity of frozen fish. J Fish Res Board Can. 1965;22:53-67.

19. Cormier A, Léger LW. Effect of sodium polyphosphates on frozen cod fillets (gadus morhua). Can Inst Food Sci Technol J. 1987;20:222-8.

20. Hill VR, Polaczyk AL, Hahn D, Narayanan J, Cromeans TL, Roberts JM, et al. Development of a rapid method for simultaneous recovery of diverse microbes in drinking water by ultrafiltration with sodium polyphosphate and surfactants. Appl Environ Microbiol. 2005;71:6878-84.

21. Cordell D, Rosemarin A, Schröder JJ, Smit AL. Towards global phosphorus security: a systems framework for phosphorus recovery and reuse options. Chemosphere. 2011;84:747-58.

22. Arias-Estévez M, López-Periago E, Martínez-Carballo E, SimalGándara J, Mejuto JC, García-Río L. The mobility and degradation of pesticides in soils and the pollution of groundwater resources. Agric Ecosyst Environ. 2008;123:247-60.

23. Guyton KZ, Loomis D, Grosse Y, El Ghissassi F, BenbrahimTallaa L, Guha N, et al. Carcinogenicity of tetrachlorvinphos, parathion, malathion, diazinon, and glyphosate. Lancet Oncol. 2015;16:490-1.

24. Chaufan G, Coalova I, Ríos de Molina MDC. Glyphosate commercial formulation causes cytotoxicity, oxidative effects, and apoptosis on human cells: differences with its active ingredient. Int J Toxicol. 2014;33:29-38.

25. Thongprakaisang S, Thiantanawat A, Rangkadilok N, Suriyo T, Satayavivad J. Glyphosate induces human breast cancer cells growth via estrogen receptors. Food Chem Toxicol. 2013;59:129-36.

26. Mink PJ, Mandel JS, Sceurman BK, Lundin JI. Epidemiologic studies of glyphosate and cancer: a review. Regul Toxicol Pharmacol. 2012;63:440-52.

27. International Agency for Research on Cancer. Some organophosphate insecticides and herbicides: diazinon, glyphosate, malathion, parathion, and tetrachlorvinphos. IARC Monogr Eval Carcinog Risks Hum. 2015;112:1-92.

28. Secretaría de Economía. Muestreo de suelos para la identificación y la cuantificación de metales y metaloides, y manejo de la muestra. 2006. http://www.cmic.org.mx/comisiones/Sectoriales/ medioambiente/Varios/Leyes_y_Normas_SEMARNAT/NMX/ Contaminaci\%C3\%B3n\%20del\%20Suelo/2.2006.pdf

29. Medio Ambiente y Recursos Naturales S de. Criterios para determinar las concentraciones de remediación de suelos contaminados por arsénico, bario, berilio, cadmio, cromo hexavalente, mercurio, níquel, plata, plomo, selenio, talio y/o vanadio. 2006. http://www.profepa.gob.mx/innovaportal/file/1392/1/nom-147semarnat_ssa1-2004.pdf

30. Atlas RM. Handbook of microbial media. 4th edition. Washington, DC: CRC Press; 2010.2043 p.

31. Bradford MM. A rapid and sensitive method for the quantitation of microgram quantities of protein utilizing the principle of protein-dye binding. Anal Biochem. 1976;72:248-54.

32. Waiman C, Avena MJ, Garrido M, Fernández Band B, Zanini GP. A simple and rapid spectrophotometric method to quantify the herbicide glyphosate in aqueous media. Application to adsorption isotherms on soils and goethite. Geoderma. 2012;170:154-8.

33. Kulakova AN, Hobbs D, Smithen M, Pavlov E, Gilbert JA, Quinn $\mathrm{JP}$, et al. Direct quantification of inorganic polyphosphate in microbial cells using 4-6-diamidino-2-phenylindole (DAPI). Environ Sci Technol. 2011;45:7799-803.

34. Tan G-Y, Chen C-L, Li L, Ge L, Wang L, Razaad I, et al. Start a research on biopolymer polyhydroxyalkanoate (PHA): a review. Polymers. 2014;6:706-54.

35. FOCUS. Guidance document on estimating persistence and degradation kinetics from environmental fate studies on pesticides in EU registration. Report of the FOCUS Work Group on Degradation Kinetics. 2006. p.1-436.

36. Kumar S, Stecher G, Tamura K. MEGA7: molecular evolutionary genetics analysis version 7.0 for bigger datasets. Mol Biol Evol. 2016;33:1870-4.

37. Lim BL, Yeung P, Cheng C, Hill JE. Distribution and diversity of phytate-mineralizing bacteria. ISME J. 2007;140:321-30.

38. Sabullah MK, Rahman MF, Ahmad SA, Sulaiman MR, Shukor MS, Shamaan NA, et al. Isolation and characterization of a molybdenumreducing and glyphosate-degrading Klebsiella oxytoca strain SAW5 in soils from Sarawa. AGRIVITA . 2016;38:1-13.

39. Yu X, Yu T, Yin G, Dong Q, An M, Wang H, et al. Glyphosate biodegradation and potential soil bioremediation by Bacillus subtilis strain Bs-15. Genet Mol Res. 2015;14:14717-30.

40. Krzyśko-Łupicka T, Kręcidło Ł, Koszałkowska M. The ability of selected bacteria to grow in the presence of glyphosate. Ecol Chem Eng A. 2015;22:185-93.

41. Kryuchkova YV, Burygin GL, Gogoleva NE, Gogolev YV, Chernyshova MP, Makarov OE, et al. Isolation and characterization of a glyphosate-degrading rhizosphere strain, Enterobacter cloacae K7. Microbiol Res. 2014;169:99-105.

42. Shushkova TV, Ermakova IT, Sviridov AV, Leontievsky AA. Biodegradation of glyphosate by soil bacteria: Optimization of cultivation and the method for active biomass storage. Microbiology. 2012;81:44-50.

43. Rueppel ML, Brightwell BB, Schaefer J, Marvel JT. Metabolism and degradation of glyphosate in soil and water. J Agric Food Chem. 1977;25:517-28.

44. Balthazor TM, Hallas LE. Glyphosate-degrading microorganisms from industrial activated sludge. Appl Environ Microbiol [Internet]. 1986;51:432-4.

45. Wackett LP, Wanner BL, Venditti CP, Walsh CT. Involvement of the phosphate regulon and the psid locus in carbon-phosphorus lyase activity of Escherichia coli K-12. J Bacteriol. 1987;169:1753-6.

46. Pipke R, Amrhein N Degradation of the phosphonate herbicide glyphosate by Arthrobacter atrocyaneus ATCC 13752. Appl Environ Microbiol. 1988;54:1293-6. http://www.ncbi.nlm.nih. gov/pubmed/16347639

47. Dick RE, Quinn JP. Glyphosate-degrading isolates from environmental samples: occurrence and pathways of degradation. Appl Microbiol Biotechnol. 1995;43:545-50.

48. Fitzgibbon J, Braymer HD. Phosphate starvation induces uptake of glyphosate by Pseudomonas sp. strain PG2982. Appl Environ Microbiol. 1988;54:1886-8.

49. Wanner BL. Molecular genetics of carbon-phosphorus bond cleavage in bacteria. Biodegrad. 1994;5:175-84.

50. White AK, Metcalf WW. Two C-P lyase operons in Pseudomonas stutzeri and their roles in the oxidation of phosphonates, phosphite, and hypophosphite. J Bacteriol [Internet]. 2004;186:4730-9.

51. Lamarche MG, Wanner BL, Crépin S, Harel J. The phosphate regulon and bacterial virulence: a regulatory network connecting phosphate homeostasis and pathogenesis. FEMS Microbiol Rev. 2008;32:461-73. 
52. Wanner BL. Signal transduction in the control of phosphateregulated genes of Escherichia coli. Kidney Int. 1996;49:964-7.

53. McGrath JW, Ternan NG, Quinn JP. Utilization of organophosphonates by environmental micro-organisms. Lett Appl Microbiol. 1997;24:69-73.

54. Kessler B, Witholt B. Factors involved in the regulatory network of polyhydroxyalkanoate metabolism. J Biotechnol. 2001;86:97-104.

55. Renier ML, Kohn DH. Development and characterization of a biodegradable polyphosphate. J Biomed Mater Res. 1997;34:95-104.

56. Undabeytia T, Morillo E, Maqueda C. FTIR study of glyphosatecopper complexes. J Agric Food Chem. 2002;50:1918-21.

57. Metcalf WW, Wanner BL. Involvement of the Escherichia coli phn ( $p s i D)$ gene cluster in assimilation of phosphorus in the form of phosphonates, phosphite, $\mathrm{Pi}$ esters, and Pi. J Bacteriol. 1991;173:587-600.

58. Vera M, Pagliai F, Guiliani N, Jerez CA. The chemolithoautotroph Acidithiobacillus ferrooxidans can survive under phosphatelimiting conditions by expressing a C-P Lyase operon that allows it to grow on phosphonates. Appl Environ Microbiol. 2008;74:1829-35.

59. Dyhrman ST, Chappell PD, Haley ST, Moffett JW, Orchard ED, Waterbury JB, et al. Phosphonate utilization by the globally important marine diazotroph Trichodesmium. Nature. 2006;439:68-71.

60. Lerbs W, Stock M, Parthier B. Physiological aspects of glyphosate degradation in Alcaligenes spec. strain GL. Arch Microbiol. 1990;153:146-50.

61. Pipke R, Amrhein N. Isolation and characterization of a mutant of Arthrobacter sp. Strain GLP-1 Which utilizes the herbicide glyphosate as its sole source of phosphorus and nitrogen. Appl Environ Microbiol. 1988;54:2868-70.

62. Zboinska E, Lejczak B, Kafarski P. Organophosphonate utilization by the wild-type strain of Pseudomonas fluorescens. Appl Environ Microbiol. 1992;58:2993-9.

63. McGrath JW, Wisdom GB, McMullan G, Larkin MJ, Quinn JP. The purification and properties of phosphonoacetate hydrolase, a novel carbon-phosphorus bond-cleavage enzyme from pseudomonas fluorescens 23F. Eur J Biochem. 1995;234:225-30.

64. McGrath JW, Kulakova AN, Quinn JP. A comparison of three bacterial phosphonoacetate hydrolases from different environmental sources. J Appl Microbiol. 1999;86:834-40.

65. Kulakova AN, Wisdom GB, Kulakov LA, Quinn JP. The purification and characterization of phosphonopyruvate hydrolase, a novel carbon-phosphorus bond cleavage enzyme from Variovorax sp Pal2. J Biol Chem. 2003;278:23426-31.

66. Kulakova AN, Kulakov LA, Villarreal-Chiu JF, Gilbert JA, McGrath JW, Quinn JP. Expression of the phosphonoalaninedegradative gene cluster from Variovorax sp. Pal2 is induced by growth on phosphonoalanine and phosphonopyruvate. FEMS Microbiol Lett. 2009;292:100-6.

67. Stenfors Arnesen LP, Fagerlund A, Granum PE. From soil to gut: Bacillus cereus and its food poisoning toxins. FEMS Microbiol Rev. 2008;32:579-606.

68. Hoornstra D, Andersson MA, Teplova VV, Mikkola R, Uotila LM, Andersson LC, et al. Potato crop as a source of emetic bacillus cereus and cereulide-induced mammalian cell toxicity. Appl Environ Microbiol. 2013;79:3534-43.

69. Altayar M, Sutherland AD. Bacillus cereus is common in the environment but emetic toxin producing isolates are rare. J Appl Microbiol. 2006;100:7-14.

70. Condon C. Molecular biology of RNA processing and decay in prokaryotes. Elsevier Academic Press; (Cambridge, Massachusetts, USA) 2009. p.510.

71. Achbergerová L, Nahálka J. Polyphosphate - an ancient energy source and active metabolic regulator. Microb Cell Fact. 2011;10:63.

72. Rao NN, Gómez-García MR, Kornberg A. Inorganic polyphosphate: essential for growth and survival. Annu Rev Biochem. 2009;78:605-47.

73. Shi X, Rao NN, Kornberg A. Inorganic polyphosphate in Bacillus cereus: motility, biofilm formation, and sporulation. Proc Natl Acad Sci USA. 2004;101:17061-5. 